\title{
Immune Evasion of the CD1d/NKT Cell Axis
}

\author{
Randy R. Brutkiewicz, Laura Yunes-Medina, and Jianyun Liu \\ Department of Microbiology and Immunology, Indiana University School of Medicine, Indianapolis, \\ IN 46202-5181
}

\begin{abstract}
Many reviews on the CD1d/NKT cell axis focus on the ability of CD1d-restricted NKT cells to serve as effector cells in a variety of disorders, be they infectious diseases, cancer or autoimmunity. In contrast, here, we discuss the ways that viruses, bacteria and tumor cells can evade the CD1d/NKT cell axis. As a result, these disease states have a better chance to establish a foothold and potentially cause problems for the subsequent adaptive immune response, as the host tries to rid itself of infections or tumors.
\end{abstract}

\section{Introduction}

Classical antigen presentation in the cellular adaptive immune response occurs via the recognition of peptides presented by the major histocompatibility complex (MHC) class I or class II molecules, to conventional T lymphocytes [1,2]. In contrast, the MHC class I-like CD1d molecule presents lipids to natural killer T (NKT) cells [3]. Invariant NKT cells are defined as those $\mathrm{CD} 1 \mathrm{~d}$-specific $\mathrm{T}$ cells that have an invariant $\mathrm{T}$ cell a chain rearrangement (Va14-Ja18 in mouse; Va24-Ja18 in humans). As part of the innate immune response, the $\mathrm{CD1d} / \mathrm{NKT}$ cell axis has been shown to play various protective roles in anti-microbial and anti-tumor host defense [4-8]. However, several pathogens and tumor cells have various means to impair antigen (Ag) presentation by CD1d and/or NKT cell function.

CD1d acquires the lipid antigens it presents by an intracellular mechanism (Figure 1). CD1d molecules are synthesized in the endoplasmic reticulum and are loaded with a non-antigenic lipid $[3,9,10]$. Like other glycosylated proteins, they then traverse through the Golgi and are ultimately expressed on the cell surface [11]. However, these CD1d molecules are not loaded with a lipid that can stimulate NKT cells. Instead, thanks to a tyrosine-based endosomal targeting sequence [12], CD1d molecules re-enter the cells and traffic through late endocytic compartments, where the non-antigenic lipid is replaced by one that is. Upon re-expression on the cell surface, NKT cells can be activated [13]. In cancer, this process is metabolically "revved up" [14]. During certain virus infections, the intracellular location of CD1d is

Corresponding author: Brutkiewicz, Randy R. (rbrutkie@iu.edu).

Publisher's Disclaimer: This is a PDF file of an unedited manuscript that has been accepted for publication. As a service to our customers we are providing this early version of the manuscript. The manuscript will undergo copyediting, typesetting, and review of the resulting proof before it is published in its final citable form. Please note that during the production process errors may be discovered which could affect the content, and all legal disclaimers that apply to the journal pertain. 
altered [15]. We measure NKT cell activation in co-cultures (i.e., NKT cells with CD1d+ cells) by the release of cytokines (e.g., IL-2, IFN- $\gamma$, IL-4, GM-CSF, etc.) by the NKT cells.

This review will discuss the immune evasion strategies various pathogens and cancer cells use against the CD1d/NKT cell axis, which could provide potential future approaches to counter those measures. Figure 2 shows the different players reported to be able to impair the CD1d/NKT cell axis; many of these mechanisms are multi-functional. We will break down the immune evasion strategies, by discussing the different diseases individually: 1 . Viruses; 2. Bacteria; 3. Tumor cells.

\section{Immune evasion by viruses}

Viruses have the capacity to impact the CD1d/NKT cell axis at both the CD1d+ antigen presenting cell (APC) and NKT cell levels. In fact, the simple act of a virus infection results in the loss of a large percentage of NKT cells by activation-induced cell death [16,17]. Interestingly, the decrease in NKT cells appears to be IL-12-dependent, yet CD1dindependent [17]; IL-12 itself can cause the apoptotic loss of NKT cells [18]. That being said, administration of the NKT cell activating and CD1d-presented, synthetic glycolipid agalactosylceramide (a-GalCer; ref. [19]) to mice infected with murine cytomegalovirus (MCMV) or lymphocytic choriomeningitis virus (LCMV), results in enhanced viral clearance $[20,21]$.

On top of this effect, viruses can target APCs. An acute LCMV infection in vivo causes a reduction in CD1d expression on dendritic cells and macrophages [22]; this may be due, in part, to alterations in cellular metabolism, resulting in a "danger signal" used by the CD1d/NKT cell axis as part of the innate immune response [23]. Importantly, cytopathic viruses are able to impact the functional expression of CD1d in multiple ways. After a vaccinia virus (VV) or vesicular stomatitis virus (VSV) infection, CD1d molecules are segregated to one side of a cell; this is concomitant with alterations in cell signaling pathways $[10,15,24,25]$. The VV-encoded proteins, B1R and H5R, and VSV matrix protein, also contribute to impairing $\mathrm{Ag}$ presentation by CD1d post-infection [24,25]. Herpes simplex virus-1 (HSV-1) alters the recycling of human CD1d [26,27], likely by inducing the phosphorylation of residues in its cytoplasmic tail $[28,29]$. Moreover, two HSV-1 encoded proteins, VP22 and US3, have been reported to contribute to the impairment of CD1dmediated Ag presentation post-HSV-1 infection [30-32]. The inhibition of NKT cell activation by HSV-1 is APC/NKT cell contact-dependent [33]. An MCMV infection results in a substantial reduction in myeloid progenitor cells in the bone marrow and spleen, especially in NKT cell- and CD1d-deficient mice [34]; this could be prevented by the adoptive transfer of NKT cells into wildtype and NKT cell-deficient mice before infection [34].

A human immunodeficiency virus (HIV) infection can target both NKT cells and CD1d+ APCs. NKT cells are reduced following infection with HIV [35-38] or simian immunodeficiency virus (SIV) [39]; this NKT cell loss is reversed quickly upon highly active antiretroviral therapy (HAART) [40]. In APCs, HIV causes a reduction in CD1d expression by the formation of a CD1d/Nef complex [41,42]. In contrast, an HIV-1 infection 
of dendritic cells can result in a TLR7-dependent upregulation of CD1d, triggering NKT cell recognition of those cells [43]. The herpesvirus KSHV also affects both CD1d expression and NKT cell numbers $[44,45]$, whereas the human papillomavirus E5 protein inhibits calnexin-dependent trafficking of CD1d [46]. Taken together, the reports indicate that viruses have multiple mechanism(s) whereby they impair CD1d-mediated Ag presentation or directly affect NKT cells.

\section{Bacterial Infections and CD1d}

There has been a variety of work describing bacterial infections that can impact the CD1d/NKT cell axis. For the most part, CD1d-mediated Ag presentation to NKT cells helps, rather than hurts, a host's anti-bacterial host defense. An example of this is the requirement for CD1d in anti-Borrelia responses [47] and the identification of diacylglycerols from Borrelia burgdorferi (causative agent of Lyme Disease) as an NKT cell-stimulating Ag [48]. As indicated above with certain virus infections, $\mathrm{a}$-GalCer has also been shown to protect mice against a Mycobacterium tuberculosis infection [49].

In other animal models (e.g., CD1d- or Ja18-deficient mice), the growth of Pseudomonas aeruginosa, Streptococcus pneumoniae, Sphingomonas and Ehrlichia muris is exacerbated as compared to wildtype mice [50]. For Sphingomonas, this makes sense, as this bacterium contains a-glucoronosylceramide, which can be presented by CD1d and activate NKT cells [51-53]. Additionally, S. pneumoniae has diacylglycerol-containing glycolipids that can stimulate NKT cells [54]. Early following a Listeria monocytogenes infection, there is a transient reduction in IL-4-producing NKT cells [55,56]. In contrast, IFN- $\gamma$-producing NKT cells expand quickly post-infection [57]. Other bacteria, such as Chlamydia, have been shown to be less pathogenic in CD1d-deficient mice, in a mouse pneumonitis model [58]. Also in that report and in line with the results in CD1d KO mice, the activation of NKT cells enhanced Chlamydia growth in vivo. This seemed to be dependent upon the Chlamydia species, as the production of Th1 vs. Th 2 cytokines upon NKT cell activation in vivo, resulted in reduced or enhanced bacterial growth, respectively [59]. Specifically, $C$. muridarum grew better when NKT cells were present, whereas a $C$. pneumoniae infection was controlled by NKT cells in vivo [60]. Others have reported that CD1d is degraded in $C$. trachomatis-infected human epithelial cells [61]. The anthrax lethal toxin impairs CD1dmediated Ag presentation by targeting the ERK1/2 mitogen-activated protein kinase [62]; a signaling pathway that we showed promotes Ag presentation by CD1d [15].

Thus, bacteria have the ability to affect the CD1d/NKT cell axis by either enhancing NKT cell-dependent responses against infection, or by directly altering the functional expression of CD1d on antigen presenting cells.

\section{Immune evasion by cancer}

Although the majority of work studying the CD1d/NKT cell axis has been in the innate anticancer immune response [63], tumor cells have been notorious for evading the immune system. Thus, overall, how do we develop cancer if our immune system is apparently "OK"? One way in which cancer cells can prevent immune attack by antitumor effector T cells (e.g., 
CD8+ CTL and NKT cells) is by simply downregulating $\beta_{2}$ microglobulin $\left(\beta_{2} \mathrm{~m}\right)$. As both MHC class I and CD1d molecules are associated with $\beta_{2} \mathrm{~m}$, this allows a tumor to kill two birds with one stone and is a common means of immune evasion by melanoma and colorectal carcinoma, for example [64]. CD1d+tumors have the capacity to evade recognition by NKT cells by shedding glycolipids, which presumably replace endogenous lipids bound to CD1d, and which cannot be recognized by NKT cells. These glycolipids include gangliogtriaosylceramide shed by the murine T cell lymphoma line, L5178Y-R [14], or the ganglioside GD3 by human ovarian cancer cells [65]. Cells that constitute the blood cancer multiple myeloma are CD1d+ [66]; however, as the disease progresses, the level of CD1d is decreased [67]. Additionally, MM patients have defects in NKT cell function in vivo; this is "reversible", in that a-GalCer can activate these NKT cells ex vivo [66].

Moreover, advanced prostate cancer patients have a reduction in circulating NKT cells; those that do exist are defective in their ability to produce IFN- $\gamma$ [68].

Immune responses to tumors are not generally polarized toward a single arm (e.g., only innate). Both the innate and adaptive immune responses will work together as a network with one arm regulating another and vice versa [69]. Overall, immune evasion mechanisms can impair one or more elements of the immunological network; alternatively, the tumors themselves can shed immunosuppressive (or CD1d blocking) glycolipds or reduce their own surface CD1d which reduces circulating NKT cells. Understanding those mechanisms will reveal potential targets for novel therapeutic paradigms using the CD1d/NKT cell axis.

\section{Conclusions}

In this review, we briefly discussed the ways in which a variety of viruses, bacteria and tumors can impair the CD1d/NKT cell axis. This can be by affecting the antigen presenting cells, by either down regulating CD1d itself or disrupting cell signaling pathways.

Alternatively, impacts on NKT cell numbers and function can also prevent a significant antimicrobial pathogen or anti-tumor immune response in a host. That being said, understanding the ways in which microbial pathogens and tumors can evade host defense, will provide insight into the identification of new targets one could use in novel treatment paradigms--in each of these disease states.

\section{Acknowledgments}

We would like to thank the members of the Brutkiewicz laboratory who have contributed to much of the work cited in this review and helped us think about immune evasion in new ways. This work was supported by the National Institutes of Health (grant numbers AI46455, CA89026 and CA161178) and, the Leukemia and Lymphoma Society. The funding agencies had no involvement in the writing of this review. We apologize to all investigators whose research could not be appropriately cited due to space limitations.

\section{References and recommended reading}

Papers of particular interest, published within the period of review, have been highlighted as:

- of special interest (in text, labeled as red font)

•• of outstanding interest (in text, labeled as light blue font) 
1. Wearsch PA, Cresswell P. The quality control of MHC class I peptide loading. Curr Opin Cell Biol. 2008; 20:624-631. [PubMed: 18926908]

2. Roche PA, Furuta K. The ins and outs of MHC class II-mediated antigen processing and presentation. Nat Rev Immunol. 2015; 15:203-216. [PubMed: 25720354]

3. McEwen-Smith RM, Salio M, Cerundolo V. CD1d-dependent endogenous and exogenous lipid antigen presentation. Curr Opin Immunol. 2015; 34:116-125. [PubMed: 25805574]

4. Shekhar S, Joyee AG, Yang X. Invariant natural killer T cells: boon or bane in immunity to intracellular bacterial infections? J Innate Immun. 2014; 6:575-584. [PubMed: 24903638]

5. Brigl M, Brenner MB. How invariant natural killer T cells respond to infection by recognizing microbial or endogenous lipid antigens. Semin Immunol. 2010; 22:79-86. [PubMed: 19948416]

6. Kinjo Y, Ueno K. iNKT cells in microbial immunity: recognition of microbial glycolipids. Microbiol Immunol. 2011; 55:472-482. [PubMed: 21434991]

7•. Shissler SC, Bollino DR, Tiper IV, Bates JP, Derakhshandeh R, Webb TJ. Immunotherapeutic strategies targeting natural killer T cell responses in cancer. Immunogenetics. 2016; 68:623-638. This review discusses the roles of Type I and Type II NKT cells in cancer and potential immunotherapeutic strategies. [PubMed: 27393665]

8. Opasawatchai A, Matangkasombut P. iNKT Cells and their potential lipid ligands during viral infection. Front Immunol. 2015; 6:378. [PubMed: 26257744]

9. Barral DC, Brenner MB. CD1 antigen presentation: how it works. Nat Rev Immunol. 2007; 7:929941. [PubMed: 18037897]

10 . Brutkiewicz RR. Cell signaling pathways that regulate antigen presentation. J Immunol. 2016; 197:2971-2979. This recent review discusses how various cell signaling pathways impact antigen presentation by CD1d, MHC class I and MHC class II molecules. [PubMed: 27824592]

11. Roberts TJ, Sriram V, Spence PM, Gui M, Hayakawa K, Bacik I, Bennink JR, Yewdell JW, Brutkiewicz RR. Recycling CD1d1 molecules present endogenous antigens processed in an endocytic compartment to NKT cells. J Immunol. 2002; 168:5409-5414. [PubMed: 12023333]

12. Bonifacino JS, Traub LM. Signals for sorting of transmembrane proteins to endosomes and lysosomes. Annu Rev Biochem. 2003; 72:395-447. [PubMed: 12651740]

13. Moody DB, Porcelli SA. Intracellular pathways of CD1 antigen presentation. Nat Rev Immunol. 2003; 3:11-22. [PubMed: 12511872]

14. Sriram V, Cho S, Li P, O'Donnell PW, Dunn C, Hayakawa K, Blum JS, Brutkiewicz RR. Inhibition of glycolipid shedding rescues recognition of a CD1+ T cell lymphoma by natural killer T (NKT) cells. Proc Natl Acad Sci U S A. 2002; 99:8197-8202. [PubMed: 12060764]

15. Renukaradhya GJ, Webb TJ, Khan MA, Lin YL, Du W, Gervay-Hague J, Brutkiewicz RR. Virusinduced inhibition of CD1d1-mediated antigen presentation: reciprocal regulation by $\mathrm{p} 38$ and ERK. J Immunol. 2005; 175:4301-4308. [PubMed: 16177070]

16. Hobbs JA, Cho S, Roberts TJ, Sriram V, Zhang J, Xu M, Brutkiewicz RR. Selective loss of natural killer $\mathrm{T}$ cells by apoptosis following infection with lymphocytic choriomeningitis virus. J Virol. 2001; 75:10746-10754. [PubMed: 11602716]

17. Lin Y, Roberts TJ, Wang CR, Cho S, Brutkiewicz RR. Long-term loss of canonical NKT cells following an acute virus infection. Eur J Immunol. 2005; 35:879-889. [PubMed: 15724241]

18. Eberl G, MacDonald HR. Rapid death and regeneration of NKT cells in anti-CD3 $\varepsilon$ - or IL-12treated mice: a major role for bone marrow in NKT cell homeostasis. Immunity. 1998; 9:345-353. [PubMed: 9768754]

19. Kawano T, Cui J, Koezuka Y, Toura I, Kaneko Y, Motoki K, Ueno H, Nakagawa R, Sato H, Kondo E, et al. CD1d-restricted and TCR-mediated activation of Va 14 NKT cells by glycosylceramides. Science. 1997; 278:1626-1629. [PubMed: 9374463]

20. van Dommelen SL, Tabarias HA, Smyth MJ, Degli-Esposti MA. Activation of natural killer (NK) $\mathrm{T}$ cells during murine cytomegalovirus infection enhances the antiviral response mediated by NK cells. J Virol. 2003; 77:1877-1884. [PubMed: 12525622]

21. Kim MK, Lee A, Hwang YK, Kang CY, Ha SJ. Enhancing T cell immune responses by B cellbased therapeutic vaccine against chronic virus infection. Immune Netw. 2014; 14:207-218. [PubMed: 25177253] 
22. Lin Y, Roberts TJ, Spence PM, Brutkiewicz RR. Reduction in CD1d expression on dendritic cells and macrophages by an acute virus infection. J Leukoc Biol. 2005; 77:151-158. [PubMed: 15548574]

23•. Webb TJ, Carey GB, East JE, Sun W, Bollino DR, Kimball AS, Brutkiewicz RR. Alterations in cellular metabolism modulate CD1d-mediated NKT-cell responses. Pathog Dis. 2016:74. This paper showed that altering the metabolism of antigen presenting cells affects CD1d-mediated antigen presentation to NKT cells.

24. Renukaradhya GJ, Khan MA, Shaji D, Brutkiewicz RR. Vesicular stomatitis virus matrix protein impairs CD1d-mediated antigen presentation through activation of the p38 MAPK pathway. J Virol. 2008; 82:12535-12542. [PubMed: 18815300]

25. Webb TJ, Litavecz RA, Khan MA, Du W, Gervay-Hague J, Renukaradhya GJ, Brutkiewicz RR. Inhibition of CD1d1-mediated antigen presentation by the vaccinia virus B1R and H5R molecules. Eur J Immunol. 2006; 36:2595-2600. [PubMed: 16981180]

26. Yuan W, Dasgupta A, Cresswell P. Herpes simplex virus evades natural killer T cell recognition by suppressing CD1d recycling. Nat Immunol. 2006; 7:835-842. [PubMed: 16845396]

27. Raftery MJ, Winau F, Kaufmann SH, Schaible UE, Schonrich G. CD1 antigen presentation by human dendritic cells as a target for herpes simplex virus immune evasion. J Immunol. 2006; 177:6207-6214. [PubMed: 17056550]

28. Liu J, Glosson NL, Du W, Gervay-Hague J, Brutkiewicz RR. A Thr/Ser dual residue motif in the cytoplasmic tail of human CD1d is important for the down-regulation of antigen presentation following a herpes simplex virus 1 infection. Immunology. 2013; 140:191-201. [PubMed: 23710894]

29. Liu J, Shaji D, Cho S, Du W, Gervay-Hague J, Brutkiewicz RR. A threonine-based targeting signal in the human CD1d cytoplasmic tail controls its functional expression. J Immunol. 2010; 184:4973-4981. [PubMed: 20368272]

30••. Liu J, Gallo RM, Duffy C, Brutkiewicz RR. A VP22-null HSV-1 is impaired in inhibiting CD1dmediated antigen presentation. Viral Immunol. 2016; 29:409-416. This study showed that the HSV-1-encoded VP22 protein is required (but not sufficient) for the inhibition of antigen presentation by CD1d following an HSV-1 infeciton. [PubMed: 27327902]

31. Rao P, Pham HT, Kulkarni A, Yang Y, Liu X, Knipe DM, Cresswell P, Yuan W. Herpes simplex virus 1 glycoprotein B and US3 collaborate to inhibit CD1d antigen presentation and NKT cell function. J Virol. 2011; 85:8093-8104. [PubMed: 21653669]

32••. Xiong R, Rao P, Kim S, Li M, Wen X, Yuan W. Herpes simplex virus 1 US3 phosphorylates cellular KIF3A to downregulate CD1d expression. J Virol. 2015; 89:6646-6655. This paper showed that the HSV-1-encoded kinase, US3, can phosphorylate the host's type II kinesin motor protein KIF3A, which is important for the downregulation of CD1d expression post-infection. [PubMed: 25878107]

33. Bosnjak L, Sahlstrom P, Paquin-Proulx D, Leeansyah E, Moll M, Sandberg JK. Contact-dependent interference with invariant NKT cell activation by herpes simplex virus-infected cells. J Immunol. 2012; 188:6216-6224. [PubMed: 22581860]

34. Broxmeyer HE, Dent A, Cooper S, Hangoc G, Wang ZY, Du W, Gervay-Haque J, Sriram V, Renukaradhya GJ, Brutkiewicz RR. A role for natural killer T cells and CD1d molecules in counteracting suppression of hematopoiesis in mice induced by infection with murine cytomegalovirus. Exp Hematol. 2007; 35:87-93. [PubMed: 17379092]

35. Fleuridor R, Wilson B, Hou R, Landay A, Kessler H, Al-Harthi L. CD1d-restricted natural killer T cells are potent targets for human immunodeficiency virus infection. Immunology. 2003; 108:3-9. [PubMed: 12519296]

36. Motsinger A, Haas DW, Stanic AK, Van Kaer L, Joyce S, Unutmaz D. CD1d-restricted human natural killer T cells are highly susceptible to human immunodeficiency virus 1 infection. J Exp Med. 2002; 195:869-879. [PubMed: 11927631]

37. Sandberg JK, Fast NM, Palacios EH, Fennelly G, Dobroszycki J, Palumbo P, Wiznia A, Grant RM, Bhardwaj N, Rosenberg MG, et al. Selective loss of innate CD4(+) Va 24 natural killer T cells in human immunodeficiency virus infection. J Virol. 2002; 76:7528-7534. [PubMed: 12097565] 
38. van der Vliet HJ, von Blomberg BM, Hazenberg MD, Nishi N, Otto SA, van Benthem BH, Prins M, Claessen FA, van den Eertwegh AJ, Giaccone G, et al. Selective decrease in circulating Va 24+Vß11+ NKT cells during HIV type 1 infection. J Immunol. 2002; 168:1490-1495. [PubMed: 11801694]

39. Motsinger A, Azimzadeh A, Stanic AK, Johnson RP, Van Kaer L, Joyce S, Unutmaz D. Identification and simian immunodeficiency virus infection of CD1d-restricted macaque natural killer T cells. J Virol. 2003; 77:8153-8158. [PubMed: 12829854]

40. van der Vliet HJ, van Vonderen MG, Molling JW, Bontkes HJ, Reijm M, Reiss P, van Agtmael MA, Danner SA, van den Eertwegh AJ, von Blomberg BM, et al. Cutting edge: Rapid recovery of NKT cells upon institution of highly active antiretroviral therapy for HIV-1 infection. J Immunol. 2006; 177:5775-5778. [PubMed: 17056500]

41. Chen N, McCarthy C, Drakesmith H, Li D, Cerundolo V, McMichael AJ, Screaton GR, Xu XN. HIV-1 down-regulates the expression of CD1d via Nef. Eur J Immunol. 2006; 36:278-286. [PubMed: 16385629]

42. Cho S, Knox KS, Kohli LM, He JJ, Exley MA, Wilson SB, Brutkiewicz RR. Impaired cell surface expression of human CD1d by the formation of an HIV-1 Nef/CD1d complex. Virology. 2005; 337:242-252. [PubMed: 15916790]

43••. Paquin-Proulx D, Gibbs A, Bachle SM, Checa A, Introini A, Leeansyah E, Wheelock CE, Nixon DF, Broliden K, Tjernlund A, et al. Innate invariant NKT cell recognition of HIV-1-infected dendritic cells Is an early detection mechanism targeted by viral immune evasion. J Immunol. 2016; 197:1843-1851. This paper showed that a Nef- and Vpu-deficient HIV-1 infection of dendritic cells causes the upregulation of CD1d in a TLR7-dependent manner, suggesting that iNKT cell recogntion of CD1d following an HIV-1 infection is one mechansim of early immune detection. [PubMed: 27481843]

44. Sanchez DJ, Gumperz JE, Ganem D. Regulation of CD1d expression and function by a herpesvirus infection. J Clin Invest. 2005; 115:1369-1378. [PubMed: 15864354]

45••. Sbihi Z, Dossier A, Boutboul D, Galicier L, Parizot C, Emarre A, Hoareau B, Dupin N, Marcelin AG, Oudin A, et al. iNKT and memory B-cell alterations in HHV-8 multicentric Castleman disease. Blood. 2017; 129:855-865. This study found that patients with multicentric Castleman Disease (which is caused by human herpesvirus 8 ), have a paucity of circulating NKT cells and a concomitant decrease in marginal zone memory B cells. [PubMed: 28060720]

46. Miura S, Kawana K, Schust DJ, Fujii T, Yokoyama T, Iwasawa Y, Nagamatsu T, Adachi K, Tomio A, Tomio K, et al. CD1d, a sentinel molecule bridging innate and adaptive immunity, is downregulated by the human papillomavirus (HPV) E5 protein: a possible mechanism for immune evasion by HPV. J Virol. 2010; 84:11614-11623. [PubMed: 20810727]

47. Kumar H, Belperron A, Barthold SW, Bockenstedt LK. Cutting edge: CD1d deficiency impairs murine host defense against the spirochete, Borrelia burgdorferi. J Immunol. 2000; 165:47974801. [PubMed: 11046002]

48. Kinjo Y, Tupin E, Wu D, Fujio M, Garcia-Navarro R, Benhnia MR, Zajonc DM, Ben-Menachem G, Ainge GD, Painter GF, et al. Natural killer T cells recognize diacylglycerol antigens from pathogenic bacteria. Nat Immunol. 2006; 7:978-986. [PubMed: 16921381]

49. Chackerian A, Alt J, Perera V, Behar SM. Activation of NKT cells protects mice from tuberculosis. Infect Immun. 2002; 70:6302-6309. [PubMed: 12379709]

50. Kinjo Y, Kronenberg M. Va 14 iNKT cells are innate lymphocytes that participate in the immune response to diverse microbes. J Clin Immunol. 2005; 25:522-533. [PubMed: 16380816]

51. Kinjo Y, Wu D, Kim G, Xing GW, Poles MA, Ho DD, Tsuji M, Kawahara K, Wong CH, Kronenberg M. Recognition of bacterial glycosphingolipids by natural killer T cells. Nature. 2005; 434:520-525. [PubMed: 15791257]

52. Mattner J, Debord KL, Ismail N, Goff RD, Cantu C 3rd, Zhou D, Saint-Mezard P, Wang V, Gao Y, Yin N, et al. Exogenous and endogenous glycolipid antigens activate NKT cells during microbial infections. Nature. 2005; 434:525-529. [PubMed: 15791258]

53. Sriram V, Du W, Gervay-Hague J, Brutkiewicz RR. Cell wall glycosphingolipids of Sphingomonas paucimobilis are CD1d-specific ligands for NKT cells. Eur J Immunol. 2005; 35:1692-1701. [PubMed: 15915536] 
54. Kinjo Y, Illarionov P, Vela JL, Pei B, Girardi E, Li X, Li Y, Imamura M, Kaneko Y, Okawara A, et al. Invariant natural killer T cells recognize glycolipids from pathogenic Gram-positive bacteria. Nat Immunol. 2011; 12:966-974. [PubMed: 21892173]

55. Emoto M, Emoto Y, Kaufmann SH. Interleukin-4-producing CD4+ NK1. 1+ TCR a/ $\beta$ intermediate liver lymphocytes are down-regulated by Listeria monocytogenes. Eur J Immunol. 1995; 25:33213325. [PubMed: 8566018]

56. Emoto Y, Emoto M, Kaufmann SH. Transient control of interleukin-4-producing natural killer T cells in the livers of Listeria monocytogenes-infected mice by interleukin-12. Infect Immun. 1997; 65:5003-5009. [PubMed: 9393789]

57. Emoto M, Yoshizawa I, Emoto Y, Miamoto M, Hurwitz R, Kaufmann SH. Rapid development of a $\gamma$ interferon-secreting glycolipid/CD1d-specific Va14+ NK1. 1-T-cell subset after bacterial infection. Infect Immun. 2006; 74:5903-5913. [PubMed: 16988270]

58. Bilenki L, Wang S, Yang J, Fan Y, Joyee AG, Yang X. NK T cell activation promotes Chlamydia trachomatis infection in vivo. J Immunol. 2005; 175:3197-3206. [PubMed: 16116210]

59. Joyee AG, Qiu H, Wang S, Fan Y, Bilenki L, Yang X. Distinct NKT cell subsets are induced by different Chlamydia species leading to differential adaptive immunity and host resistance to the infections. J Immunol. 2007; 178:1048-1058. [PubMed: 17202368]

60. Shekhar S, Joyee AG, Yang X. Dynamics of NKT-cell responses to Chlamydial infection. Front Immunol. 2015; 6:233. [PubMed: 26029217]

61. Kawana K, Quayle AJ, Ficarra M, Ibana JA, Shen L, Kawana Y, Yang H, Marrero L, Yavagal S, Greene SJ, et al. CD1d degradation in Chlamydia trachomatis-infected epithelial cells is the result of both cellular and chlamydial proteasomal activity. J Biol Chem. 2007; 282:7368-7375. [PubMed: 17215251]

62. Khan MA, Gallo RM, Brutkiewicz RR. Anthrax lethal toxin impairs CD1d-mediated antigen presentation by targeting the extracellular signal-related kinase $1 / 2$ mitogen-activated protein kinase pathway. Infect Immun. 2010; 78:1859-1863. [PubMed: 20194602]

63. Nair S, Dhodapkar MV. Natural killer T cells in cancer immunotherapy. Front Immunol. 2017; $8: 1178$. This recent review discusses the current state of the art in the use of NKT cells against cancer. [PubMed: 29018445]

64. Bernal M, Ruiz-Cabello F, Concha A, Paschen A, Garrido F. Implication of the $\beta_{2}$-microglobulin gene in the generation of tumor escape phenotypes. Cancer Immunol Immunother. 2012; 61:13591371. [PubMed: 22833104]

65. Webb TJ, Li X, Giuntoli RL 2nd, Lopez PH, Heuser C, Schnaar RL, Tsuji M, Kurts C, Oelke M, Schneck JP. Molecular identification of GD3 as a suppressor of the innate immune response in ovarian cancer. Cancer Res. 2012; 72:3744-3752. [PubMed: 22649190]

66. Dhodapkar MV, Geller MD, Chang DH, Shimizu K, Fujii S, Dhodapkar KM, Krasovsky J. A reversible defect in natural killer $\mathrm{T}$ cell function characterizes the progression of premalignant to malignant multiple myeloma. J Exp Med. 2003; 197:1667-1676. [PubMed: 12796469]

67. Spanoudakis E, Hu M, Naresh K, Terpos E, Melo V, Reid A, Kotsianidis I, Abdalla S, Rahemtulla A, Karadimitris A. Regulation of multiple myeloma survival and progression by CD1d. Blood. 2009; 113:2498-2507. [PubMed: 19056691]

68. Tahir SM, Cheng O, Shaulov A, Koezuka Y, Bubley GJ, Wilson SB, Balk SP, Exley MA. Loss of IFN- $\gamma$ production by invariant NK T cells in advanced cancer. J Immunol. 2001; 167:4046-4050. [PubMed: 11564825]

69. Robertson FC, Berzofsky JA, Terabe M. NKT cell networks in the regulation of tumor immunity. Front Immunol. 2014; 5:543. [PubMed: 25389427] 


\section{Highlights}

- Viruses, bacteria and tumors can impair the CD1d/NKT cell axis

- $\quad \mathrm{CD} 1 \mathrm{~d}$ can be downregulated or cell signaling pathways disrupted

- NKT cells can be directly infected and/or unable to recognize CD1d

- Immune evasion strategies might be used to develop new treatments paradigms 


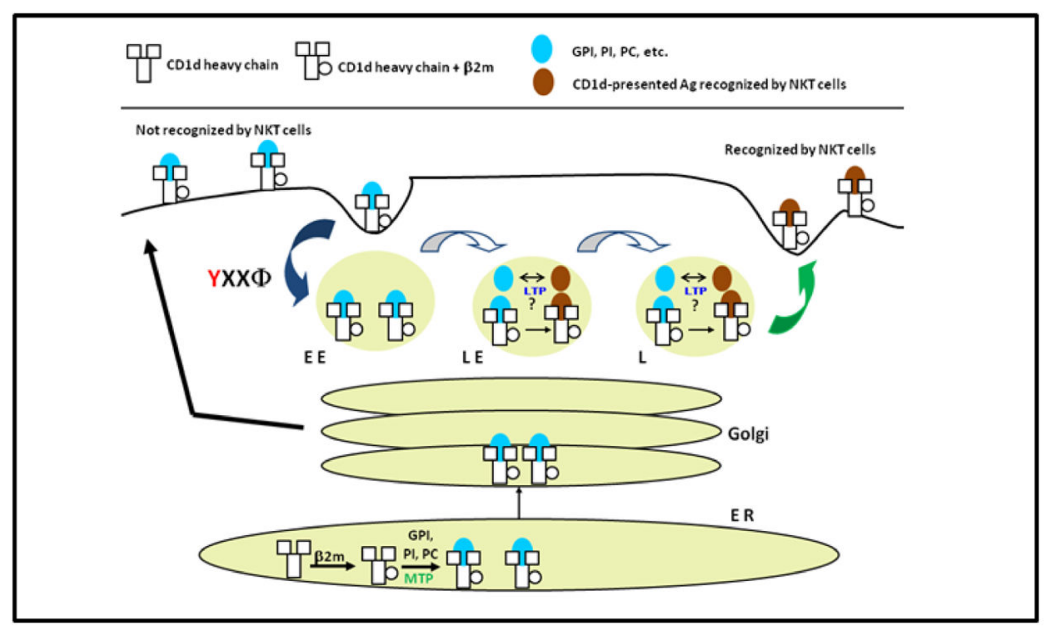

Figure 1. Intracellular trafficking of CD1d molecules

CD1d molecules are synthesized in the endoplasmic reticulum (ER) and form a complex with $\beta_{2}$ m. It is within this compartment that CD1d is loaded with an endogenous glycolipid (GPI, PI, PC, etc.), facilitated by the microsomal triglyceride transfer protein (MTP). The complex then traverses through the Golgi complex and onto the cell surface. These lipidloaded molecules cannot be recognized by NKT cells. A Tyr-based endosomal targeting sequence (YXXФ) causes the CD1d1- $\beta_{2}$ m-lipid complex to reenter the cell and traffic to intracellular vesicular compartments in the endocytic pathway. It is there that the first lipid can be replaced by the appropriate endogenous $\operatorname{Ag}(\mathrm{s})$ by a lipid transfer protein (LTP); it then returns to the cell surface, where it can now be recognized by NKT cells. EE, early endosomes; LE, late endosomes or early lysosomes; L, lysosomes. Modified from Roberts et al., Recycling CD1d1 molecules present endogenous antigens processed in an endocytic compartment to NKT cells, J. Immunol. 168:5409 - 5414, 2002. Copyright 2002. The American Association of Immunologists, Inc. 


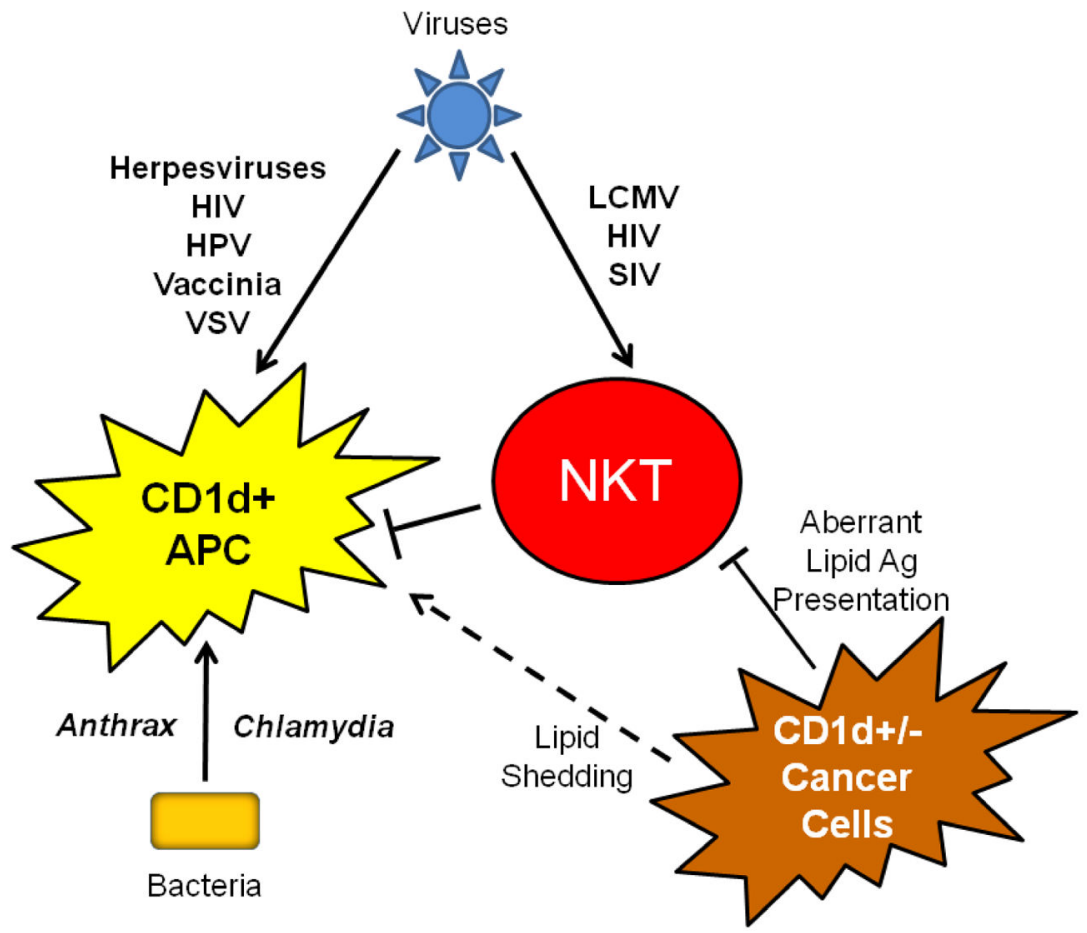

Figure 2. Immune evasion targets

Viruses, bacteria and tumor cells have various means to evade the CD1d/NKT cell axis.

Various viruses can target APCs and/or NKT cells, either directly or indirectly. Bacteria can infect APCs and impair the functional expression of CD1d. Lastly, can tumor cells can present aberrant lipids to NKT cells, effectively preventing their activation; alternatively, tumor cells can shed glycolipids from their membranes, binding to CD1d on normal APCs and preventing their recognition by NKT cells. 